\title{
STUDY ON EXTRACTION AND PURIFICATION OF TRANS-RESVERATROL FROM VINE WASTE - A REVIEW
}

\author{
* Alina Lenuța CRĂCIUN ${ }^{\mathbf{1}}$, Gheoghe GUTT ${ }^{\mathbf{1}}$ \\ ${ }^{I}$ Faculty of Food Engineering, Ștefan cel Mare University, Suceava, Romania, \\ alina.craciun@usm.ro, \\ *Corresponding author \\ Received $25^{\text {th }}$ April 2021, accepted $28^{\text {th }}$ June 2021
}

\begin{abstract}
Resveratrol (3, 4', 5-trihydroxystilbene) is a natural phenolic compound synthesized by plants in response to various stressful circumstances (mechanical injury, siege of bacteria or fungi and UV exposure). Commercial resveratrol supplements on the market are mostly extracted from Japanese knotweed. As it grows even in heavily polluted environments and the presence of emodin, which is a compound that may have laxative effects and is found in partially purified extracts, additional concerns about the safety of these commercial preparations were raised. An alternative source of resveratrol intensely studied in recent years is vine waste, with recent studies showing high concentrations of resveratrol in extracts. In the last years, the researcher's attention is focused on obtaining an efficient method of extraction and purification of this compound from the vine waste to show that this material can be used as a raw material for production of commercial supplements of resveratrol.
\end{abstract}

Keywords: trans-resveratrol; vine waste; purification; supplements; health

\section{Introduction}

Human food was composed since the Paleolithic era of products of plant origin and hunted, this dividing the tribes into gatherers and hunters. Over time, human has evolved and thus his diet has evolved, becoming more and more diversified, especially with the domestication of animals and the cultivation of land. If in the recent years the possibility of having many foods meant wealth, now people's preferences tend towards a healthier lifestyle and diet [1].

Although the general tendency is to have a lifestyle as healthy as possible, food cannot stop the oxidative processes that take place in the body and cause aging or disease. Recent studies focus on obtaining compounds that slow down oxidative processes, using substances of plant origin with high availability [2]. Resveratrol (3, 4', 5-trihydroxystilbene) is a natural phenolic compound of plant origin. It belongs to the category of stilbenes, which are secondary metabolites of plants with a "stilbene skeleton" comprising two aromatic rings linked to an alkene [3].

It was found that some plants synthesize resveratrol in response to various stressful circumstances (damage, exposure to high doses of ultraviolet radiation, fungal parasites, etc.). It is found in both stereoisomeric forms (cis - in very small amounts and trans which is the most present) and is fat-soluble [4]. This compound is found in grapes (only in the skin and in different amounts depending on the variety, region and exposure to fungal infections), hazelnuts, and berries of the 
family Vaccinum (red and black currants, blueberries, cranberries) [5]. Resveratrol is found in different amounts in grapes and vines, the largest amount being in the stem, followed by grape skin, seeds and pulp [6]. The first article on resveratrol appeared in 1939 [7]. The presence of resveratrol in red wine was first discovered by researchers at Cornell University, Siemann and Creasy in 1992 [5]. This finding linked the compound to the famous "French paradox", a term derived from epidemiological research that showed that the mortality rate due to cardiovascular disease was significantly lower in the French population compared to other European countries, despite their higher cholesterol and saturated animal fat intake [8]. Subsequent research has suggested that the lower risk of cardiovascular disease may be attributed to the habit of consuming red wine more often among the French [9].

The product is already available on the market in various forms. The market for this supplement is constantly growing because demand is higher than supply, and this product has uses in the pharmaceutical, cosmetic and food industries. Due to the growing demand for resveratrol supplements, the interest of researchers in the extraction and purification of resveratrol from vineyard waste has increased, so this new opportunity for waste recovery was extensively studied in recent years [10].

The purpose of this work was to highlight the progress and summarize the data obtained by researchers in the extraction and purification of resveratrol from vine wastes and thus show that this material can be used as a raw material for production of commercial supplements of resveratrol.

\section{Resveratrol and its characteristics}

Table 1. shows beside identification elements and technical security data, the physicochemical properties required in extraction, detection and purification of resveratrol.

Identification elements, physicochemical properties and technical safety data of resveratrol [11]

\begin{tabular}{|c|c|}
\hline \multicolumn{2}{|l|}{ Resveratrol } \\
\hline \multicolumn{2}{|l|}{ Identification elements } \\
\hline Other names & $\begin{array}{c}\text { trans-3,5,4'-Trihydroxystilbene } \\
\text { 3,4 ', 5-Stylbenetriol } \\
\text { trans-Resveratrol } \\
\text { (E)-5-(p-Hydroxystyryl) resorcinol } \\
\text { (E)-5-(4-hydroxystyryl)benzene-1,3-diol }\end{array}$ \\
\hline CAS number & $501-36-0$ \\
\hline \multicolumn{2}{|l|}{ Physicochemical properties } \\
\hline Chemical formula & $\mathrm{C}_{14} \mathrm{H}_{12} \mathrm{O}_{3}$ \\
\hline Molar mass & $228.25 \mathrm{~g} / \mathrm{mol}$ \\
\hline Appearance & White powder with slightly yellowish hues \\
\hline Boiling point & $528^{\circ} \mathrm{C}$ \\
\hline Melting point & $261-263^{\circ} \mathrm{C},\left(502-505^{\circ} \mathrm{F}, 534-536 \mathrm{~K}\right)$ \\
\hline Solubility in water & $0.03 \mathrm{~g} / \mathrm{L}$ \\
\hline Solubility in dimethylsulfoxide & $16 \mathrm{~g} / \mathrm{L}$ \\
\hline Solubility in ethanol & $50 \mathrm{~g} / \mathrm{L}$ \\
\hline $\mathrm{UV}$-vis $\left(\lambda_{\max }\right)$ & $\begin{array}{l}304 \mathrm{~nm} \text { (trans-resveratrol, in aqueous solution) } \\
286 \mathrm{~nm} \text { (cis-resveratrol, in aqueous solution) }\end{array}$ \\
\hline \multicolumn{2}{|l|}{ Technical security data } \\
\hline Risk phrases & R36 - Irritating to eyes \\
\hline Safety phrases & $\begin{array}{c}\text { S } 26 \text { - In case of contact with eyes, rinse immediately } \\
\text { with plenty of water and seek medical advice }\end{array}$ \\
\hline Lethal dose LD50 & $5.29 \mathrm{~g}$ \\
\hline
\end{tabular}

Alina Lenuța CRĂCIUN, Gheorghe GUTT, Study on extraction and purification of trans-resveratrol from grape cane - A review, Food and Environment Safety, Volume XX, Issue - 2021, pag. 113-127 
3. Effects of resveratrol to human body

Resveratrol has a lot of beneficial effects on human health, these being shown in

fig. 1 and detailed below.

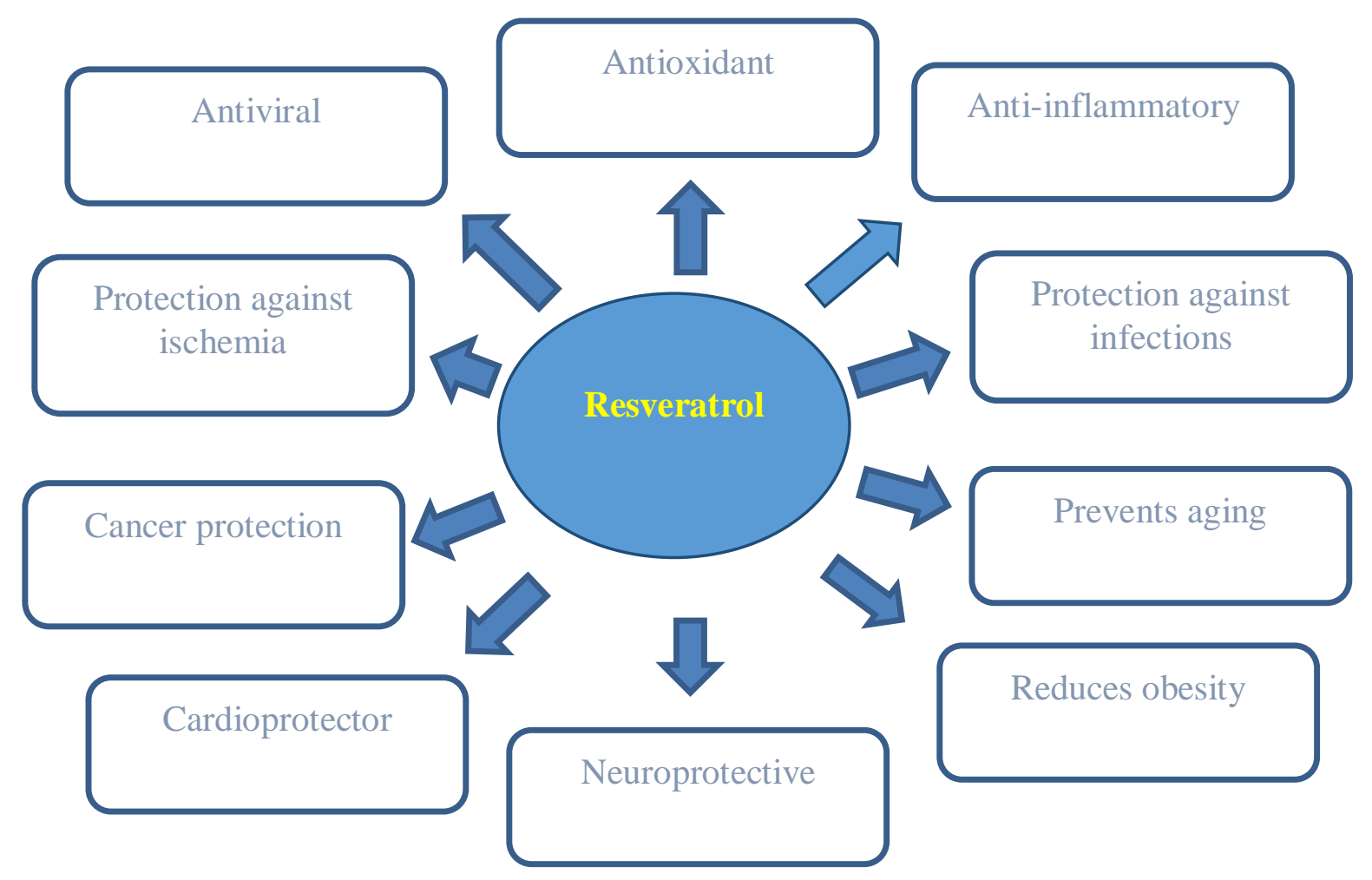

Fig.1. The beneficial effects of resveratrol [1]

\subsection{Slowing down the aging process}

One of the most sought after properties of any chemical supplement is its ability to rejuvenate cells and tissues to extend their lifespan. Some of the early evidence for resveratrol's ability to extend cell life comes from the work of Howitz et al. in 2003, who show that resveratrol in the yeast Saccharomyces cerevisiae has the effect of increasing the stability of genomic DNA through various signals, resulting in an overall life extension of $70 \%$. These results prompted further research into the anti-aging effect of the compound and its adaptation to treat agingrelated disorders such as dementia or Alzheimer's disease [12].

A study by Kumar et al. in 2006 found that a $20 \mathrm{mg} / \mathrm{kg}$ body dose of resveratrol has the ability to regenerate depleted areas of hippocampal tissue in the brains of older mice [13]. Another study conducted by preliminary tests of 20000 compounds and studies in mice showed that resveratrol has the most promising life-extending abilities [2].

These findings have brought resveratrol to the attention of researchers, highlighting its potential to be developed as a therapeutic agent for neurodegenerative diseases related to aging.

\subsection{The antioxidant activity of resveratrol}

The best known health benefit of resveratrol is its ability to act as an antioxidant. Being a phenolic compound, resveratrol can act against free radicals and also as a promoter of cellular antioxidant enzymes such as glutathione, peroxidase, glutathione-transferase and glutathione reductase to induce neutralization of radical peroxides [14]. Based on the in vitro study of Shang et al. since 2009, a 
reaction mechanism has been proposed for the antioxidant activity of resveratrol, galvinoxyl radicals and 2,2-diphenyl-1picrilhydrazyl (DPPH) [15].

Other in vitro studies that mimic physiological systems and biological systems such as mouse pheochromocytoma cell lines have shown that resveratrol is a potent antioxidant compared to a number of typical food additives such as tocopherols, butylated hydroxyanizole (BHA), butyl hydroxytoluene (BHT) and vanillin [16].

Because of the findings that suggest that reactive oxygen species are linked to cardiovascular disease, various cancers, diabetes, and periodontal disease, the antioxidant activity of resveratrol makes this compound a potential therapeutic agent against these diseases [17].

\subsection{Inhibition of enzymes responsible for skin aging and pigmentation}

The main enzymes responsible for aging, pigmentation and dull appearance of the skin are tyrosinase, hyaluronase, collagenase and elastase. Resveratrol was found to inhibit the activity of these enzymes and the results showed that its effect is concentration-dependent [2].

\subsection{Antibacterial effects of resveratrol}

\subsubsection{Effect against Propionibacterium}

\section{acnes}

The appearance and progression of acne is due to $P$. acnes, which is part of the resident microbiota in the hair follicles of human skin. $P$. acnes multiplies using sebum as a source of nutrients and produces lipase. It degrades sebum triglycerides, releases fatty acids and induces a series of inflammatory reactions. White blood cells "wander" and infiltrate the dermis and release the inflammatory factor. It irritates the skin and accelerates the cornification of the epidermis with inflammation [18]. By performing an assay on an agar culture medium to which resveratrol was added, it was shown that it controls the multiplication of $P$. acnes starting at a concentration of $300 \mu \mathrm{g} / \mathrm{mL}$ or higher [2].

\subsubsection{Effect against Helicobacter pylori}

Helicobacter pylori is a bacteria that causes gastric ulcer and stomach cancer and lives in the stomach. The Japanese have high degrees of infection with $H$. pylori, as over $50 \%$ of the population over 60 is affected. The antibacterial activity of resveratrol is effective against $H$. pylori, and was confirmed by in vitro tests [2].

\subsection{Antifungal effects of resveratrol}

According to Kuc's definition, phytoalexins are antimicrobial compounds synthesized and accumulated by plants in response to biotic or abiotic elicitors [19]. In the woody material of some Vitis species, resveratrol and its derivatives can accumulate up to $700 \mathrm{mg} / \mathrm{g}$ and are involved in the prevention of wood degradation and in the resistance of plants to pathogens. The antifungal properties of resveratrol have been demonstrated using bioassays. Langake et al. reported reduced fungal toxicity to resveratrol with the effective dose required for mortality of $50 \%$, a dose between 71 and $200 \mathrm{mg} / \mathrm{L}$ on $P$. viticola spores and $B$. cinerea conditions [20]. Radial growth of $B$. cinerea and $P$. viticola fungal mycelium on agar substrates decreased in the presence of a resveratrol dose of 50 to $100 \mathrm{ppm}$. Adrian et al. observed an inhibition of $B$. cinerea germination in the presence of $7 \times 10^{-4} \mathrm{M}$ resveratrol [21].

\subsection{Anti-inflammatory activity}

Inflammation, the body's response to toxins and exogenous infections, is triggered by reactive oxygen species and could lead to tissue damage and atherosclerosis [22]. The antioxidant activity of resveratrol helps reduce inflammatory responses by eliminating reactive oxygen species. However, some

Alina Lenuța CRĂCIUN, Gheorghe GUTT, Study on extraction and purification of trans-resveratrol from grape cane - A review, Food and Environment Safety, Volume XX, Issue - 2021, pag. $113-127$ 
studies suggested that resveratrol is also able to regulate inflammatory responses by disrupting the associated biochemical pathways [22]. Such a pathway involves the activation of a transcription factor known as NF- $\kappa \mathrm{B}$, which induces the expression of cellular signaling proteins (cytokines) to initiate the inflammatory response in target tissues. Resveratrol inhibits the NF- $\kappa \mathrm{B}$ pathways, resulting in decreased inflammatory signaling [23]. Therefore, the compound is useful in decreasing the inflammatory response triggered by various signals.

\subsection{Anti-carcinogenic effect}

The anti-cancer activity of resveratrol is an area that was extensively studied over the last decade. Many research results suggest that this compound has pleiotropic functionality against cancer. The antioxidant and anti-inflammatory actions of resveratrol help prevent such damage to the genetic material. In addition, many studies demonstrate that this compound plays a key role in regulating the transduction pathways of multiple signals to inhibit the progression of mutations and cancer cells [24]. The work conducted by Yi et. al. since 2013 demonstrated the ability of the compound to cause cell cycle arrest by regulating the expression of transcription factors involved in the phase of DNA synthesis in the cell cycle, even in highly aggressive malignancies such as anaplastic thyroid carcinoma and colon cancer, which are less receptive to conventional methods of treatment [24].

In addition, research results have shown that resveratrol is able to induce the expression of proteins associated with cellular apoptosis signaling pathways to cause programming of cell death in postcancer cell lines. The results also indicate that this compound has a minimal effect on healthy cell lines for inducing apoptosis. Therefore, resveratrol has the potential to be used as a selective chemotherapeutic agent for cancer [25].

\subsection{Cardioprotective effects}

The cardioprotective effects of resveratrol were discovered based on research that showed an inverse correlation between red wine consumption and the incidence of cardiovascular disease. Scientists have discovered a phenomenon called the "French paradox", which is based on the hypothesis that a moderate consumption of red wine reduces the occurrence of cardiovascular disease. All this is due to the inhibitory effect on cell membrane lipid peroxidation and protection against the oxidation of low-density lipoproteins (LDL), which influence the reduction of HDL cholesterol concentration [26].

\subsection{Protection against diseases of the nervous system}

One of the reasons for diseases of the nervous system is the deposition of $\beta$ amyloid in the brain, which does not allow the proper functioning of nerve cells, preventing their communication. This leads to memory loss or impaired cognitive function in humans, a disease also called Alzheimer's. There is more research on the use of resveratrol as a compound that helps treat Alzheimer's disease, given that this compound limits the function of $\beta$-amyloid proteins and stimulates their decay as short polypeptides and amino acids through the proteasome mechanism. This promising result can help inhibit or slow down the development of these disorders [27].

\subsection{Beneficial effects on the symptoms of diabetes}

Resveratrol was found to increase insulin sensitivity in mice on a high-calorie diet, increase lipid metabolism in diabetic mice, reduce nerve pain, and protect neurons [2].

\section{Recovery of vine waste for resveratrol extraction}


Because resveratrol is a natural phytoalexin, it is synthesized by a multitude of plants, about 700 species. The amount of resveratrol synthesized by plants varies widely, and only a few plants are of interest for its extraction and purification to obtain chemical supplements. [1]

The best known plants with a significant content of resveratrol are the vine (Vitis vinifera) and the Japanese knotweed (Polygonum cuspidatum) [28]. Recent studies in the field have brought to light other plants containing resveratrol, such as several species of spruce (Picea mariana, Picea abies, Picea glauca, Picea sichensis), hazelnuts (Arachis hypogaea), legumes (Cassia Sp., Eucalyptus globules) and others [29].

Many of the commercial preparations of resveratrol are extracted from the root of the Japanese knotweed (Polygonum cuspidatum), and vary widely in degree of purity. Some studies showed that an additional compound such as emodin is present in unpurified or partially purified resveratrol extracts, and could have a laxative effect [30]. Because the plant thrives even in environments heavily polluted with heavy metal-contaminated soils, cellular uptake of these contaminants by root tissues raises additional concerns about the safety of commercial resveratrol preparations obtained from the roots of this plant [31,32].

Another representative source for the extraction of this valuable compound is the waste from the wine industry, which abounds in this compound. Recent studies have shown the presence of this compound in significant quantities in various byproducts from the wine industry, which include: wood waste from the grooming of vines and pomace and bunches resulting from winemaking technology [33].

Viticulture is one of the most important agricultural activities in the world, with approximately $\quad 7.4$ million hectares cultivated globally in 2018, of which 4.3 million hectares are cultivated in Europe. The first country is represented by Spain, with an area of 969,000 hectares, followed by China with 875,000 hectares and France with 793,000 hectares [34]. The annual average of by-products resulting from the cleaning of the vine is $1.3 \mathrm{~kg}$ of wood/live $\log$, which results in $2 \times 10^{7}$ tons of wood harvested annually in the world. Currently, the only use of this waste is as fertilizer for vines, by grinding and distribution on vineyards [35].

The chemical composition of the vine shoots is characterized by a fraction of holocellulose, with a content of approximately $55.1 \%(31.9 \% \quad \alpha$-cellulose and $23.2 \%$ hemicellulose), and another fraction of lignin, which represents about $38.5 \%$. The most important fraction is the minor fraction, represented by phenolic and volatile compounds, those with a greater importance for the food, pharmaceutical and cosmetic industry, being the most intensively studied stilbene group [35].

Due to the growing demand for resveratrol for food supplements, researchers in many countries have turned their attention to waste resulting from winemaking technology.

The resveratrol content of the vine has been studied extensively in recent years by researchers in various countries. Aavikasar et al. determined the resveratrol content of vineyard waste from an Estonian wine region in three different seasons in 2002. These were analyzed immediately after harvest, and after prior maceration with $80 \%$ ethanol, $80 \%$ methanol and $96.6 \%$ ethanol the values were between 0.1-2.9 $\mathrm{mg} / \mathrm{g}$ dry weight (D.W.) [33]

The study conducted on the variety Vitis amurensis by Chinese researchers investigated the content of resveratrol in different plant tissues at different times. Although this study found that the content of resveratol was different depending on 
the anatomical part of the plant and varied depending on the season, the values are considerably lower than the values obtained from the analysis of vine waste. Rhizomes have the highest content of resveratrol (92.0-165.7 $\mathrm{mg} / \mathrm{kg} \quad$ D.W.), followed by roots $(76.1-123.4 \mathrm{mg} / \mathrm{kg}$ D.W.), grape skin, (30.6-63.2 $\mathrm{mg} / \mathrm{kg}$ D.W.), shoots (5.3-18.9 $\mathrm{mg} / \mathrm{kg}$ D.W.), seeds (20.4-36.5 mg/kg D.W.) and leaves (1.3-10.3 $\mathrm{mg} / \mathrm{kg}$ D.W.) The resveratrol content begins to increase in the summer months, reaching a maximum in autumn, and then decreases with the temperature [36].

The difference in resveratrol concentration in the different anatomical parts of the vine was also determined by researchers in Hungary. From the data obtained it was observed that the highest concentration of resveratrol is present in the stem $(344.5 \pm$ $32.2 \mathrm{mg} / \mathrm{kg}$ D.W.), followed by buds $(183.3 \pm 10.4 \mathrm{mg} / \mathrm{kg}$ D.W. $)$, root $(113.0 \pm$ $6.2 \mathrm{mg} / \mathrm{kg}$ D.W. $)$, grape skin $(113.0 \pm 6.2$ $\mathrm{mg} / \mathrm{kg}$ D.W. $)$, bunches (17.43 \pm 2.34 $\mathrm{mg} / \mathrm{kg} \quad$ D.W. $)$, carcasses $(2.96 \pm 0.29$ $\mathrm{mg} / \mathrm{kg} \mathrm{D.W.})$ and seeds $(0.78 \pm 0.02 \mathrm{mg} / \mathrm{kg}$ D.W.) [37].

The resveratrol content of wine waste was also analyzed by researchers in Turkey. They determined the resveratrol content of 10 different grape varieties by analyzing samples resulting from $60 \%$ ethanol extraction, and reported values ranging from $0.95 \pm 0.08$ to $3.94 \pm 0.21 \mathrm{~g} / 100 \mathrm{~g}$ D.W. [38].

As studies show, resveratrol is present in all component parts of the vine, but in different amounts. Vine waste can be a viable source for the extraction of resveratrol, both due to the high concentration of resveratrol and also due to the fact that they are economically advantageous.

\section{Optimization of methods for the extraction of resveratrol from wine waste}

The extraction efficiency can be influenced by a multitude of factors such as: the drying time and temperature of the samples, the degree of crushing, the extraction temperature and time, and the type of solvent and procedure used. For this reason, numerous studies were aimed at finding an optimal method of transresveratrol extraction. In the research conducted in the Czech Republic by Ivo Soural et al. 25 different extraction methods were compared by varying these factors [39].

Grinding of samples - In the case of extractions with cut samples and grinded samples, higher yields of trans-resveratrol were always obtained in the case of grinded samples [39].

Solvents used - Methanol is a better solvent than acetone for resveratrol extraction, the biggest difference being visible in the case of samples that were cut into pieces, where the amount of resveratrol extracted was considerably higher [39].

According to literature, the solvents with a high degree of extraction of resveratrol are ethanol and methanol, with an optimal concentration of $80 \%$ [29]. The only disadvantage of these solvents is that they have low selectivity, so alongside resveratrol are extracted other compounds that can hinder its further purification. An alternative to these solvents could be diethyl ether, which is a more selective solvent that, however, gives a lower resveratrol extraction yield [40].

Extraction temperature - The yield of resveratrol obtained by maceration of samples at room temperature was lower when using acetone than methanol. When using methanol as solvent the concentration of resveratrol was close to that obtained when macerating at higher temperatures [39].

Multiple Extractions - Multiple extractions were performed by Soxhlet extraction using methanol. The first extraction step

Alina Lenuța CRĂCIUN, Gheorghe GUTT, Study on extraction and purification of trans-resveratrol from grape cane - A review, Food and Environment Safety, Volume XX, Issue - 2021, pag. 113-127 
(with 10 cycles) had much higher yields compared to the second, third, fourth and fifth steps. The yields of all three compounds up to the second stage were below 5\%, and the yields of the third and subsequent steps were below $1 \%$ [39]. In the case of conventional maceration at room temperature with $80 \%$ methanol for 72 hours, the yield of resveratrol in the second extraction was $80 \%$ lower than in the first extraction [33].

Extraction procedure - In the study conducted by Manuela M. et al., 2018 on wine waste from 2 different varieties, the efficiency of 3 different extraction methodologies was compared: conventional extraction, microwaveassisted extraction and supercritical aqueous extraction; the results were compared based on the phenolic composition of the extracts and antioxidant capacity. The optimal parameters for each method were established using the literature in the field [41]. The experimental data obtained showed that the best extraction yield of resveratrol was obtained by microwave-assisted extraction, followed by conventional extraction and supercritical aqueous extraction (136 $\pm 7>$ $133 \pm 6>9.39 \pm 0.47 \mathrm{mg} / 100$ g D.W.) Between the first two methods a small difference in yield was observed [41].

Due to the fact that resveratrol is susceptible to photochemical isomerization, the extraction methods used must involve solvents and temperatures that do not affect the final compound. The temperature stability of resveratrol was studied by researchers in Spain for microwave-assisted extraction. For the tests, a standard solution of resveratrol was placed in the extraction vessel with $100 \%$ ethanol, and then the degree of recovery of resveratrol from these samples was analyzed at temperatures of $50{ }^{\circ} \mathrm{C}, 75^{\circ} \mathrm{C}$, $100^{\circ} \mathrm{C}, 125^{\circ} \mathrm{C}$, and $150{ }^{\circ} \mathrm{C}$. The degree of resveratrol recovery was around $90 \%$ for all temperatures [3].
The extraction methodologies performed and the solvents used can be very critical for the quality of the final compound. In the case of resveratrol, it is susceptible to photochemical isomerization [42]. Thus, the method of extracting resveratrol must include protective measures, such as the absence of light, the use of an inert atmosphere or the addition of an antioxidant with higher antioxidant properties than resveratrol. In recent years, the development and use of an extractive method has become increasingly popular because it can obtain products with higher yields and better quality [43].

Recent studies have highlighted the possibility of extracting stilbene, including resveratrol, from the vine by supercritical aqueous extraction. In the study by Julein G. et al. a supercritical aqueous extraction at $160{ }^{\circ} \mathrm{C}$ for $5 \mathrm{~min}$ led to the recovery of $1.30 \mathrm{~g} / \mathrm{kg}$ dry weight resveratrol from shoots, $2.11 \mathrm{~g} / \mathrm{kg}$ D.W. strain resveratrol and $1.52 \mathrm{~g} / \mathrm{kg} \mathrm{D.W}$. resveratrol from the roots [44].

Another alternative method of extracting resveratrol from wine waste could be extraction with low polarity water under pressure. Trans-resveratrol was extracted using this method by varying the extraction parameters. The best yield $(3.40 \mathrm{mg} / \mathrm{g}$ D.W.) was obtained when using $25 \%$ ethanol at $105{ }^{\circ} \mathrm{C}$ with a flow rate of 1 $\mathrm{mL} / \mathrm{min}$ or $15 \%$ ethanol at $105{ }^{\circ} \mathrm{C}$ with a flow rate of $5 \mathrm{~mL} / \mathrm{min}$. An increase of temperature above $105{ }^{\circ} \mathrm{C}$ or decrease of the ethanol concentration below $25 \%$ negatively affected the resveratrol concentration [42].

\section{Vine waste processing to improve resveratrol content}

Recent publications argued that resveratrol also accumulates in the post-pruning period of vine shoots. In the study conducted in France by Houille B. et al. it was shown that the concentration of transresveratrol can increase up to 40 -fold

Alina Lenuța CRĂCIUN, Gheorghe GUTT, Study on extraction and purification of trans-resveratrol from grape cane - A review, Food and Environment Safety, Volume XX, Issue - 2021, pag. $113-127$ 
during long-term storage of vine shoots [45].

In the study by Philipp E. et al. in Germany, an increase in resveratrol concentration was studied depending on the shelf life of the shoots. In the first 6 months after storage, a major increase (between $400 \%$ and 1400\%) of transresveratrol was recorded, resulting in values between $2096 \mathrm{mg} / \mathrm{kg}$ dry weight for the Regent variety and $752 \mathrm{mg} / \mathrm{kg}$ D.W. for the Cabernet Sauvignon variety [35].

Another study by Spanish researchers on vine shoots of the varieties Airèn and Cencibel showed an increase in the concentration of trans-resveratrol and other non-volatile phenolic compounds in samples kept for one month, 3 months and 6 months [35]. In the Airèn variety the concentration was $77.10 \pm 11.29 \mathrm{mg} / \mathrm{kg}$ D.W. after one month, $151.60 \pm 9.42$ $\mathrm{mg} / \mathrm{kg}$ D.W. after 3 months and $170.44 \pm$ $3.82 \mathrm{mg} / \mathrm{kg}$ D.W. after 6 months. In the Cencibel variety the concentration was $50.41 \pm 2.74 \mathrm{mg} / \mathrm{kg}$ D.W. after one month, $224.83 \pm 29.64 \mathrm{mg} / \mathrm{kg}$ D.W. after 3 months and $227.00 \pm 6.03 \mathrm{mg} / \mathrm{kg} \mathrm{D.W}$. after 6 months [35].

In the study by Billet K. et al. in France, it was analyzed the increase in the concentration of resveratrol in harvested shoots by exposure to biotic stress caused by Botrytis cinerea infection, by short-term exposure to UV light, and by mechanical stress generated by cutting shoots into sections of different lengths. After the first two attempts, no significant increase in the concentration of trans-resveratrol in the vine shoots was observed. In the third experiment the shoots were cut into sections of $0.2 \mathrm{~cm}, 0.5 \mathrm{~cm}, 1 \mathrm{~cm}, 5 \mathrm{~cm}$ and $10 \mathrm{~cm}$ and the results are presented in the figure 2.. [47] After only two weeks, cutting into $0.5 \mathrm{~cm}$ sections allowed for optimal accumulation of resveratrol, which is much faster when compared to previous data reporting the highest accumulation in 6 weeks [45], 8 weeks [47] and 20 weeks [46].

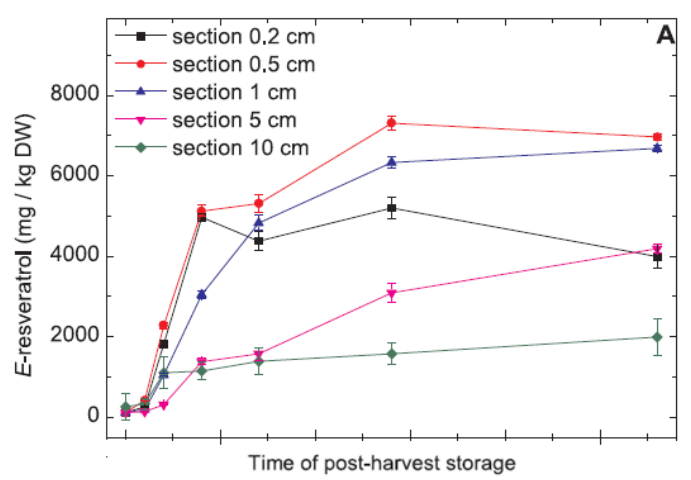

Fig.2. Accumulation of trans-resveratrol in vine shoots by storage time [46]

A study conducted in Chile showed a significant increase in the concentration of resveratrol, up to 5 times, of Pinot Noir vine residues harvested in 2012, after 2 months of storage at room temperature in the laboratory. During the storage period (8 months after cutting) the transresveratrol content increased significantly until the 2nd month, in the 3rd month a slight decrease began and then remained almost constant (Fig. 3). In the case of the shoots remaining on the plant, only a slight increase of the resveratrol concentration was observed (Fig. 4) [48].

7. Potential techniques and approaches for the development of a method for the purification of resveratrol from wine waste

In recent years, with the discovery of high resveratrol content in wine waste, a number of techniques have been investigated for the isolation and purification of resveratrol from these extracts [49]. 


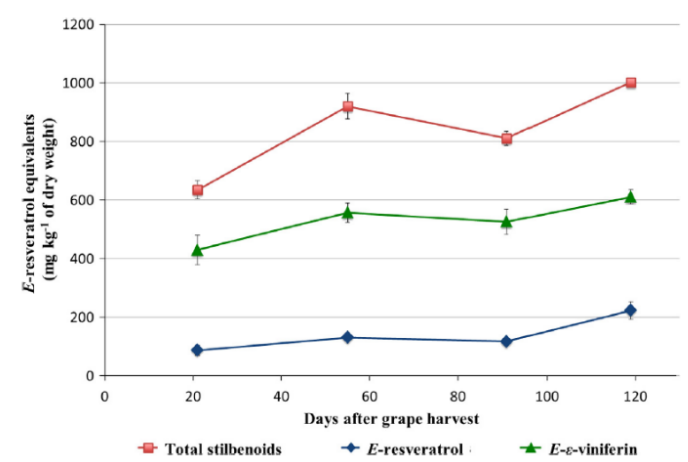

Fig. 3 Concentration of stilbenes (mg/kg D.W.) from the 2012 Pinot Noir vine branches left on the plant $[48]$

The purification of resveratrol from wine waste extracts cannot be carried out by a single process, thus for the highest possible purification it is necessary for the extract to be processed by a sequence of steps and processes [50].

In the study by Aaviksaar et al. attempts were made to extract and purify resveratrol from wine waste. In the preparative purification experiment, a mixture of vine powder from 4 different varieties, Hasaine Sladki, Jubilei Novgoroda, Marechal Joffre and Zilga was used [33]. In the first phase, the extract was purified by separation from the brown impurities. For this purpose, diethyl ether was added to the extraction solution of $96.6 \%$ ethanol in a ratio of 1: 4 diethyl ether - ethanol, because the dry extract obtained with $80 \%$ ethanol solution

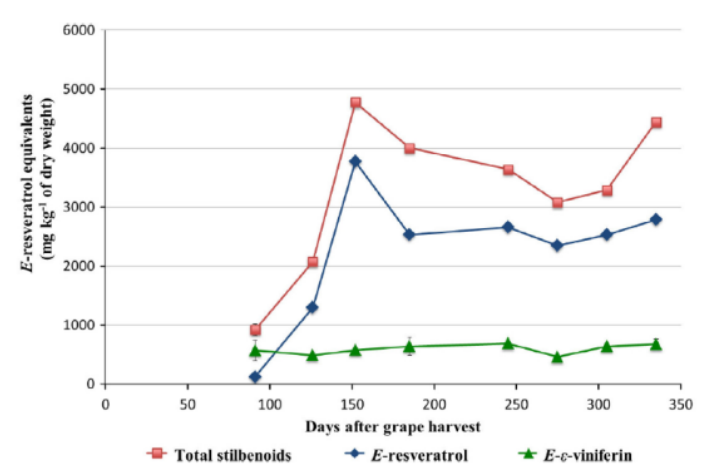

Fig. 4 Concentration of stilbenes in Pinot Noir vines from 2012, after cutting them from the plant (mg/kg D.W.) [48]

is not soluble in diethyl ether. Following the extraction with the obtained solvent, a slightly separable precipitate of brown impurities appeared in the amount of $30 \%$ of the extract. As there were no components with optical activity at $306 \mathrm{~nm}$ in the precipitate, the described diethyl ether treatment proved to be an effective method for lowering the impurity content of the extract without affecting the extraction yield of resveratrol. The next technique used to purify resveratrol was to separate it by column chromatography with polyamide support. Following HPLC analysis of the extract resulted from purification (Fig. 5), 93.8\% purity resveratrol was obtained, with a recovery rate of $77 \%$ [33].

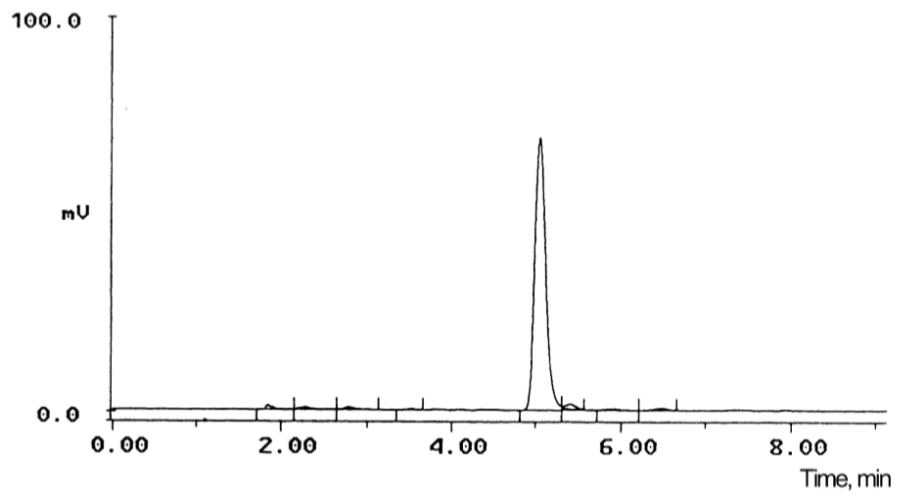

Fig. 5. Reverse phase column HPLC profile of purified trans-resveratrol ethanolic solution from vine strains by ethanolic extraction, diethyl ether treatment and column chromatography on Woelm Polyamide (93.8\% purity) [33].

Alina Lenuța CRĂCIUN, Gheorghe GUTT, Study on extraction and purification of trans-resveratrol from grape cane - A review, Food and Environment Safety, Volume XX, Issue - 2021, pag. 113 - 127 
A method for the preparative separation and purification of resveratrol from vine roots by flash chromatography was developed by Yangji $\mathrm{W}$ et al. The solution resulting from the alcoholic maceration with $70 \% \mathrm{v} / \mathrm{v}$ methanol was partially purified with $3 \%$ sodium bicarbonate solution and ethyl acetate using a separatory funnel. The obtained extract was further subjected to the purification process by flash chromatography in countercurrent. For this procedure, a phase solvent system composed of chloroform, methanol, n-butanol and water in a ratio of 4:3:0.05:2 v/v was used. The fractions of the separated peaks were collected manually according to the chromatographic profiles. All experiments were performed at room temperature. The resulting fractions were further separated by high performance liquid chromatography using a reverse phase $\mathrm{C} 18$ column. The obtained resveratrol fraction had a purity of $97.89 \%$, according to the chromatogram in Fig. 6 [51].

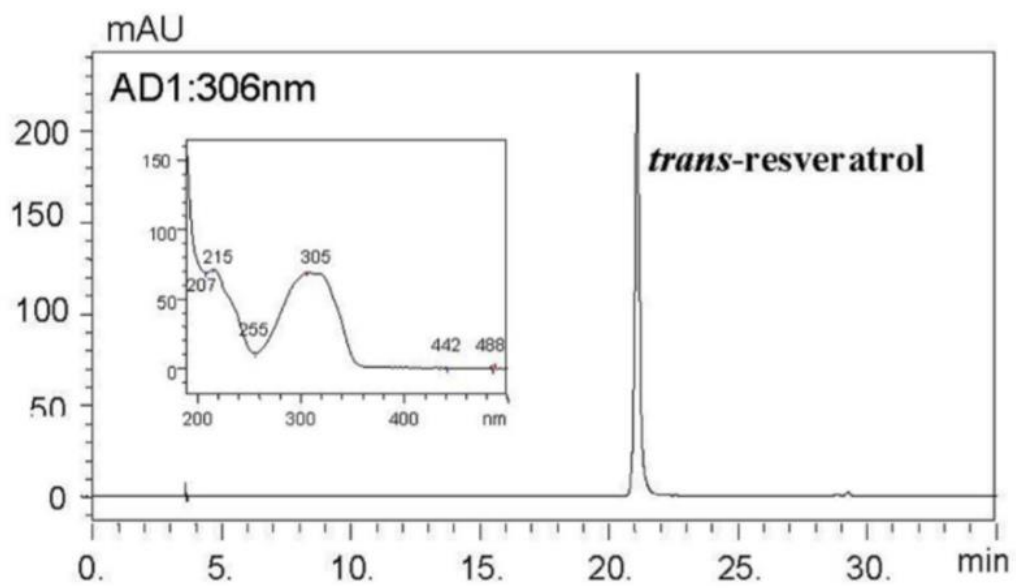

Fig. 6. HPLC chromatogram and UV spectrum of the resveratrol fraction (purity 97.89\%) [51]

Another study by Al-Jumaily et al. recommends the use of column chromatography as a process for the partial purification of extracts from wine waste. For this purpose, the partial purification of the extracts was made in an open glass column filled with special G60 silica gel filler. The extract was dissolved in 1-2 mL of methanol and the mobile phase consisted of benzene: methanol: acetic acid 20:4:1. The elution was collected in separate tubes, each tube being filled with $3 \mathrm{~mL}$ of eluent. All fractions were tested with $1 \%$ ferric chloride solution as a colorimetric test for phenol identification. Only positive results were collected and dried under vacuum in a rotary evaporator [52].

Specialized packing materials, such as Sephadex LH-20, have been frequently used in purification studies of natural substances. Sephadex LH-20 possesses a large number of hydroxyl groups in its polymeric structure, which allows a high degree of interaction with compounds from complex mixtures [39].

The work of Guder et al. demonstrated that resveratrol can be isolated in pure form from grape extracts on a Sephadex LH-20 column. The suggested purification method involves an initial step on a silica gel column, followed by separation on a Sephadex LH-20 column to obtain a pure resveratrol fraction. Despite the need to collect a large number of column fractions before eluting the target compound, this approach resulted in high purity and high yield of resveratrol from primary grape extracts [53]. Using the techniques of extraction and purification of resveratrol

Alina Lenuța CRĂCIUN, Gheorghe GUTT, Study on extraction and purification of trans-resveratrol from grape cane - A review, Food and Environment Safety, Volume XX, Issue - 2021, pag. 113 - 127 
from viticultural waste described in the literature, a partial purification of up to $93.8 \%$ [Aa, '03] or $97.89 \%$ [Ya, '14] was obtained.

In the study conducted by Piyaratne S. in 2018 on the extraction and purification of resveratrol from black spruce bark, a purification of resveratrol of $99 \%$ was obtained. Various techniques, such as liquid-liquid extraction, column chromatographic separation with multiphase silica gel (methanol, chloroform, ethyl acetate, formic acid), borate complex extraction, ion exchange column chromatography, column with Sephadex LH-20, acetylation and diacetylation of extracts, and purification on reversedphase column chromatography with $\mathrm{C} 18$ coated silica were applied in this study [54]. These tests resulted in a purification scheme comprising the following steps: liquid extraction with sodium bicarbonate, open column chromatography on silica gel with a special silica gel G60 fill, Sephadex LH-20 column chromatography with dichloromethane and methanol and reverse phase column chromatography with dichloromethane and ethyl acetate. These steps were similar to the procedures described in attempts to purify resveratrol from vine waste [17].

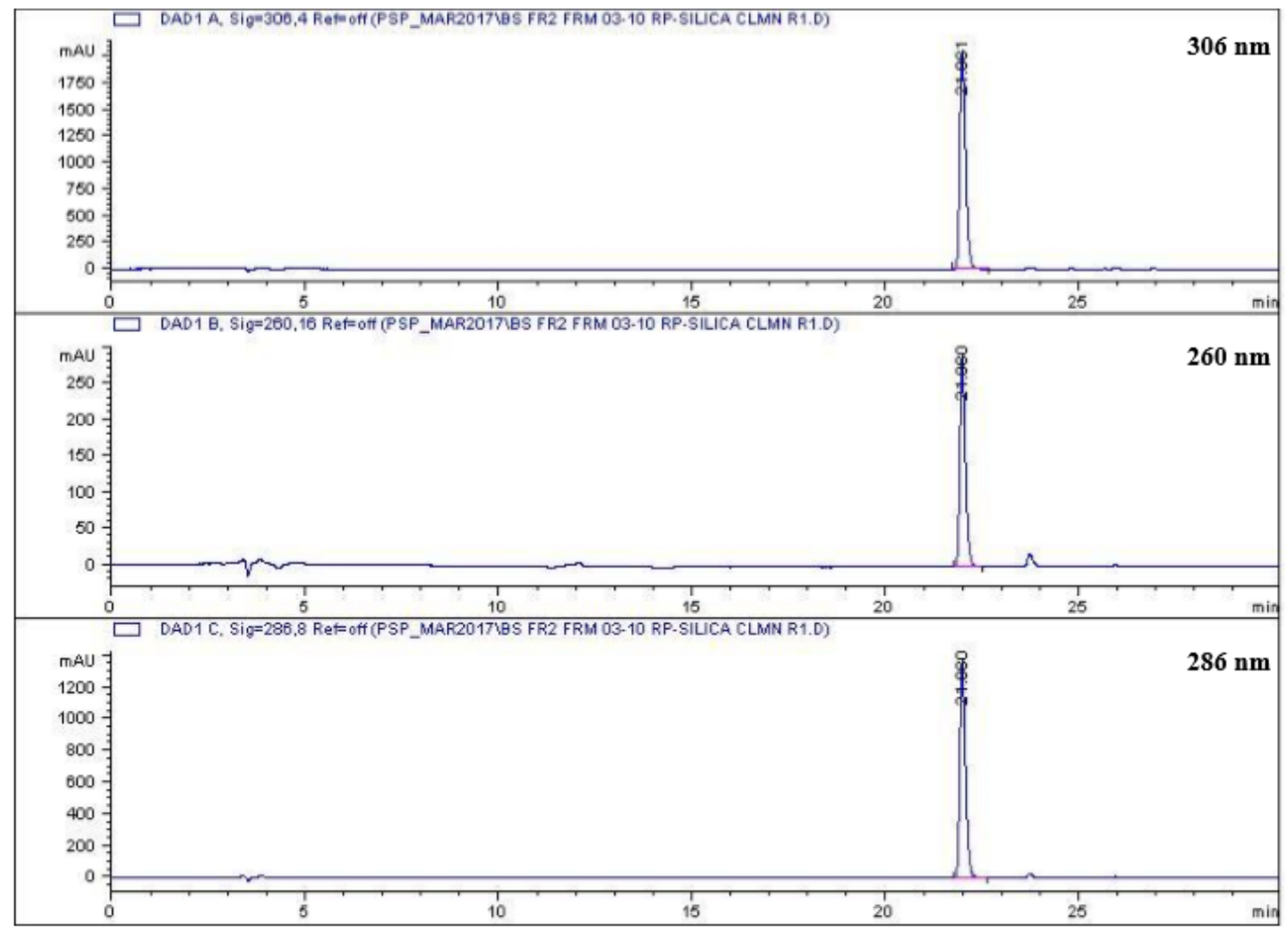

Fig. 7. HPLC-UV chromatograms obtained at $306 \mathrm{~nm}$ (maximum absorption for the transresveratrol isomer), $286 \mathrm{~nm}$ (maximum absorption for the cis-resveratrol isomer) and $206 \mathrm{~nm}$ (maximum absorption for many other phenolic compounds) for the extracts of purified resveratrol from black spruce bark [17]

The results (Fig.7.) indicate a clean peak of trans-resveratrol and a low peak of cisresveratrol. Therefore, the trans-resveratrol resulting from the purification method proposed by Piyaratne S. meets the purity level of the products available on the market. By combining and using these processes on vineyard waste it could be possible to purify resveratrol up to $99 \%$.

Alina Lenuța CRĂCIUN, Gheorghe GUTT, Study on extraction and purification of trans-resveratrol from grape cane - A review, Food and Environment Safety, Volume XX, Issue - 2021, pag. $113-127$ 


\section{Conclusion}

Studies in the field showed the beneficial effect of resveratrol on human health. Thus, the interest of researchers in obtaining high-purity commercial resveratrol preparations has increased. Vine waste could be used to obtain resveratrol due to the large amount it contains and the low purchase price. According to recent studies, the amount of resveratrol can increase up to 40 times in the vine waste after keeping them for 2 months at room temperature. Thus, they could be a very good source for the extraction of this compound for the pharmaceutical, food and cosmetics industry.

Regarding the extraction conditions, the experimental data showed that the most recommended solvents for the extraction of resveratrol from wine waste are ethanol and methanol in $80 \%$ concentration. The extraction temperature may adversely affect the extraction yield or may expose the compound to chemical isomerization. However, as the increase in temperature does not result in a significant increase of the extraction yield, it would be advisable to work with temperatures that have no effect on the chemical stability of the samples. Good yields, close to those obtained by other techniques were also achieved by macerating the samples with alcoholic solutions at $50{ }^{\circ} \mathrm{C}$.

The extraction and purification techniques of resveratrol from wine waste described in the literature achieved a partial purification of up to $93.8 \%$ or $97.89 \%$. The method of purification of resveratrol from wine wastes could be further improved to obtain a purification of resveratrol up to $99 \%$ by combining multiple processes in a succession of steps.

\section{References}

[1]. LESTER P., ENRIQUE E., Resveratrol in health and disease, University of Southern California School of Pharmacy, Los Angeles, California, (2006

[2]. ORYZA OIL \& FAT CHEMICAL CO, Tokyo, Japan, Resveratrol for Anti-ageing, Antioxidation, Neuron protection \& Metabolic Syndrome, (2008)

[3]. PINEIRO Z., MARRUFO-CURTIDO A., VELA C., PALMA M., Microwave-assisted extraction of sttilbenes from woody vine material, Food and bioproducts processing 103, pg. 1-26 (2017)

[4]. BREZOIU, A. M., MATEI, C., DEACONU, M., STANCIUC, A. M., TRIFAN, A., GASPARPINTILIESCU, A., \& BERGER, D., Polyphenols extract from grape pomace. Characterization and valorisation through encapsulation into mesoporous silica-type matrices, Food and Chemical Toxicology, 133, 110787. (2019)

[5]. Sieman E.H., Creasy L., Concentration of phytoalexin resveratrol in wine, Am. Journal, 49:52, (1992)

[6]. HE, Y. Z., WANG, B., ZHUANG, Y., \& LU, Y. P. Study on separation and purification of resveratrol in wine grape residue with aqueous two phase extraction method. In Advanced Materials Research (Vol. 550, pp. 1743-1746). Trans Tech Publications Ltd (2012)

[7]. TAKAOKA M., Resveratrol a new phenolic compound from Veratrum grandi-florum, J.Chem. Soc, Japain, 1090:1100 (1939)

[8]. RICHARD J.L., CAMBIEN F., DUCIMETIÈRE P., Epidemiologic characteristics of coronary disease in France, Nouv. Press. Med., (1981)

[9]. CHADWICK D.J., GOODE I.A., Alcohool and cardiovascular diseases, Novartis Foundation Symposium (1998)

[10]. TEIXEIRA, A., BAENAS, N., DOMINGUEZ-PERLES, R., BARROS, A., ROSA, E., MORENO, D. A., \& GARCIA-VIGUERA, C.. Natural bioactive compounds from winery byproducts as health promoters: a review. International journal of molecular sciences, 15(9), 15638-15678. (2014)

[11]. https://www.caymanchem.com $/ \mathrm{msdss} / 706$ $75 \mathrm{~m} . \mathrm{pdf}$

[12]. HOWITZ K., BIETTERMAN K.J., COHEN Y.H., LAMMING D.W.,WOOD J., ZIPKIN R.E., CHIMG P., KISIELEWSKI A, ZHANG L.L., BRANDY S., SINCLAIR D.A., Small molecule activators of sirutuins extend Saccharomyces cerevisiae lifespan, Nature 425, 191:196, (2003) [13]. KUMAR V., PANDY A., JAHAN S., SHUKLA R.K., KUMAR D., SRIVASTAVA A.,

Alina Lenuța CRĂCIUN, Gheorghe GUTT, Study on extraction and purification of trans-resveratrol from grape cane - A review, Food and Environment Safety, Volume XX, Issue - 2021, pag. $113-127$ 
SINGH S., RAJPUROHIT C, YADAV S., KHANNA Z.K., Differential responses of transresveratrol on proliferation of neuronal progenitor cells and aged rat hippocampal neurogenesis, Sci.Rep., (2016)

[14]. Lastra C.A., Villegas I, Resveratrol as an atioxidant and pro-oxidant agent: mechanisms and clinical implications, Biochem. Soc. Trans.35, 1156:1160, (2007)

[15]. SHANG V.J., QUAN Y.P., LIU X.D., DAU F, SHANG X.L., JIA W.Q., LIU Q., FANG J.G., ZHAU B., Radical-scavenging activity and mechanism of resveratrol-oriented analogues: influence of the solvent, redical, and substitution, Journal Org. Chem. 74, 5025-5031, (2009)

[16]. MURCIA M.A., MARTI'NEZ-TOME M., Antioxidant activity of resveratrol compared with common food additives, J. Food Prot. 64, 379-384, (2001)

[17]. PIYOROTNE S.P., Extraction and purification of (E)-Resveratrol from the Bark of Maine's Native Spruces, University of Maine, (2018)

[18]. SILVA, V., IGREJAS, G., FALCO, V., SANTOS, T. P., TORRES, C., OLIVEIRA, A. M., \& POETA, P., Chemical composition, antioxidant and antimicrobial activity of phenolic compounds extracted from wine industry by-products. Food Control, 92, 516-522 (2018).

[19]. KUC J, Phytoalexins, stress metabolism, and disease resistance in plants, Annu Rev Phytopathol 33, 275-297, (1995).

[20]. LANGCAKE P, Disease resistance of Vitis spp. and the production of the stress metabolites resveratrol, e-viniferin, a-viniferin and pterostilbene, Physiol Plant Pathol 18, 213-226, (1981).

[21]. ADRIAN M, JEANDET P, VENEAU J, WESTON LA, AND BESSIS R, Biological activity of resveratrol, a stilbenic compound from grapevines, against Botrytis cinerea, the causal agent for gray mold, J Chem Ecol 23(7), 16891702 (1997)

[22]. MITTAL M., SIDDIQUI M.R., TRAN K., REDDY S.P., MALIK A.B., Reactive oxygen species in inflammation and tissue injury, Antioxidant Redox Sigmal 20, 1126-1167, (2014) [23]. TIAN Y., WANG J., ZHANG L., XU J., WANG K., LI D., Resveratrol supplements inhibited the NF-kB inflammation pathway through activating AMPK $\alpha$-SIRT 1 pathway in mice with fatty live, Mol. Cel Biochem. 422, 75-84 (2016)

[24]. YIU X.M., JASKULA-SZTUL R., AHMED K., HARRISAN A.D., KUNNIMALAIYAAN M, CHEN H., Resveratrol induces differentiation markers expression in anaplastic thyroid suppresses cell growth, Mol.Cancer Ther. 12, 1276-1287, (2013)
[25]. SHANKAR S., SODDIQUI I., SRIVASTAVA R., Molecular mechanisms of resveratrol (3,4,5-trihydroxy-stilbene) and its interaction with TNF-related apoptosis inducind ligand (TRAIL) in androgen-insensitive prostate cancer cells, Moll. Cell. Biochem. 304 273-285, (2007)

[26]. FABJANOWICZ M.,PLATKA-WASYLKA J., NAMIESNIK J., Detection, identification and determination of resveratrol in wine. Problems and chalenges, Trends in Analytical Chemistry103, 21$33,(\mathbf{2 0 1 8})$

[27]. VIDAVALUR R., OTANI H., SINGAL P., MÁULIK N., Significance of wine and resveratrol in cardiovascular disease: French paradox revisited, Exp. Clin. Cordial. 11, 217-225 (2006)

[28]. WANG, D. G., LIU, W. Y., \& CHEN, G. T. A simple method for the isolation and purification of resveratrol from Polygonum cuspidatum. Journal of pharmaceutical analysis, 3(4), 241-247 (2013).

[29]. GARCIA L., GARCIA R., POCHECA G., SUTILI F., DE SOUZA F., MANSUR E., LEAL I., Optimized extraction of resveratrol from Arachis repens hancera by ultrasound and microwave: A correlation study with the antioxidant properties and phenol contents, The Scient. World J., ID 5890897, (2016)

[30]. SRINIVAS G., BABYKUTTY S., SOTHIADEVAN P., SRINIVAS P., Molecular mechanism of emodin action: transition from laxative ingredient to an antitumor agent, Med. Res. 2715, 591-608 (2007)

[31]. BERCHOVÁ-BIMOVÁ K., SOLTYSIAK J., VACH M., Role of different taxa and cytotyses in heavy metals absorption in knotweeds (Fallopia), Sci. Agric. 45,. 11-18 (2014)

[32]. BILLET, K., HOUILlÉ, B., BESSEAU, S., MÉLIN, C., OUDIN, A., PAPON, N.\& LANOUE, A., Mechanical stress rapidly induces E-resveratrol and E-piceatannol biosynthesis in grape canes stored as a freshly-pruned byproduct, Food chemistry, 240, 1022-1027. (2018)

[33]. NONOMURA, S., KANAGAWA, H., \& MAKIMOTO, A.. Chemical constituents of polygonaceous plants. i. studies on the components of ko-j o-kon.(polygonum cuspidatum sieb. et zucc.). Yakugaku zasshi, Journal of the Pharmaceutical Society of Japan, 83, 988. (1963) [34]. AAVIKASAR A., HAGA M., PURSA T., ROASTO M., TSOUPRAS G., Purification of resveratrol from vine stems, Proc. Estonian Acad, Sci, Chem. 52, pg 155-164 (2003)

[35]. http://oiv.int/public/medias/6782/oiv-2019statistical-report-on-world-vitiviniculture.pdf [36]. CEBRIÁN, C., SÁNCHEZ-GÓMEZ, R., SALINAS, M. R., ALONSO, G. L., \& ZALACAIN, A. Effect of post-pruning vine-shoots

Alina Lenuța CRĂCIUN, Gheorghe GUTT, Study on extraction and purification of trans-resveratrol from grape cane - A review, Food and Environment Safety, Volume XX, Issue - 2021, pag. $113-127$ 
storage on the evolution of high-value compounds, Industrial Crops and Products, 109, 730-736 (2017) [37]. JI, M., LI, Q., JI, H., \& LOU, H. Investigation of the distribution and season regularity of resveratrol in Vitis amurensis via HPLC-DAD-MS/MS, Food chemistry, 142, 61-65 (2014)

[38]. NÉMETH G., HEGYI O., DUNAI A., KOCSIS L., Stilbenes in the different organs of Vitis vinifera cv. Merlot grafted on TK5BB rootstock, OENO One, 51,. 323-328, (2017)

[39]. ÇETIN, E. S., ALTINÖZ, D., TARÇAN, E., \& BAYDAR, N. G.. Chemical composition of grape canes. Industrial Crops and Products, 34(1), 994-998. (2011)

[40]. SOURAL I., VRCHATOVÁ N., TRÍSKA J., BALÍK J., HORNÍK S., CURINOVÁ P., SYKORA J., Various Extraction Methods for obtaining stilbenes from grape cane of Vitis vinifera L., Molecules Journal (2015)

[41]. BRAVO, M. N., FELICIANO, R., SILVA, S., COELHO, A. V., BOAS, L. V., \& BRONZE, M. R. Analysis of trans-resveratrol: Comparison of methods and contents in Muscatel fortified wines from Setúbal region in Portugal. Journal of food composition and analysis, 21(8), 634-643, (2008).

[42]. MOREIRA M., FATIMA BARROSO M., PORTO V., RAMALHOSA M.J., ŠVARC-GAJIĆ J., ESTEVINHO L., MORAIS S., DELERUEMATOS C., "Potential of Portuguese vine shoot wastes as naturalresources of bioactive compounds", Science of total envioment 634, 831842, (2018)

[43]. KARACABEY E., MAZZA G., BAYINDIRLI L., ARTIK N., Extraction of Bioactive Compounds from Milled Grape Canes (vitis vinifera) Using a Pressurized Low-Polarity Water Extractor, Food Bioprocess Technol 5, 359371, (2012)

[44]. JU, Y., ZHANG, A., FANG, Y., LIU, M., ZHAO, X., WANG, H., \& ZHANG, Z. Phenolic compounds and antioxidant activities of grape canes extracts from vineyards. Spanish journal of agricultural research, 14(3), 18(2016).

[45]. GABASTON J., LEBORGNE C. , VALLS J., RENOUF E., RICHARD T., WAFFOTEGUO P. , MÉRILLON J., " Subcritical water extraction of stilbenes from grapevine by-products: A new green chemistry approach" IndustrialCrops\&Products 126, 272-279, (2018)

[46]. HOUILLÉ B., BESSEAU S., COURDAVAULT V., OUDIN A., GLÉVAREC G., DELANOUE G., GUÉRIN L., SIMKIN A.J., PAPON N., CLASTRE M., GIGLIOLIGUIVARC'H N., LANOUE A., Byosynthetic origin of resveratrol acummulation in grape canes during pastharvest storage, J. Agric. Food Chem. 63, 1631-1638, (2015)
[47]. BILLET, K., HOUILLÉ, B., BESSEAU, S., MÉlin, C., OUDIN, A., PAPON, N., \& LANOUE, A. Mechanical stress rapidly induces Eresveratrol and E-piceatannol biosynthesis in grape canes stored as a freshly-pruned byproduct. Food chemistry, 240, 1022-1027. (2018).

[48]. VERGARA, C., VON BAER, D., MARDONES, C., WILKENS, A., WERNEKINCK, K., DAMM, A., WINTERHALTER,P. Stilbene levels in grape cane of different cultivars in southern Chile: Determination by HPLC-DAD-MS/MS method, Journal of Agricultural and Food Chemistry, 60(4), 929-933, (2012)

[49]. GORENA, T., SAEZ, V., MARDONES, C., VERGARA, C., WINTERHALTER, P., \& VON BAER, D. „Influence of post-pruning storage on stilbenoid levels in Vitis vinifera L. Canes", Food Chemistry, 155, 256-263, (2014)

[50]. BAVARESCO, L., CANTU, E., FREGONI, M., \& TREVISAN, M. Constitutive stilbene contents of grapevine cluster stems as potential source of resveratrol in wine. VITISJournal of Grapevine Research, 36(3), 115. (2015). [51]. RAYNE, S., KARACABEY, E., \& MAZZA, G. Grape cane waste as a source of transresveratrol and trans-viniferin: High-value phytochemicals with medicinal and antiphytopathogenic applications. Industrial crops and products, 27(3), 335-340. (2008).

[52]. YANGJI WEP, PI LI1, LIYAN MA, JINGMING LP, Separation and Purification of Four Stilbenes from Vitis vinifera L. cv. Cabernet Sauvignon Roots Through High-speed Countercurrent Chromatograph ,Centre for 'Viticulture and Enology, College of Food Science and Nutritional Engineering, China Agricultural University, Beijing, 100083, P.R. China (2014)

[53]. AL-JUMAILY, E. F., HAMID, G. S., \& ALI, K. F., Synthesis and total phenol content of new resveratrol derivative. Open $\mathrm{J}$ Adv Drug Deliv, 2(3), 320-329 (2014)

[54]. GÜDER, A., KORKMAZ, H., GÖKCE, H., ALPASLAN, Y.B., ALPASLAN, G. Isolation, characterization, spectroscopic properties and quantum chemical computations of an important phytoalexin resveratrol as antioxidant component from Vitis labrusca $L$. and their chemical compositions. Spectrochim Acta Mol Biomol Spectrosc 133:378-395. (2014)

[55]. KARACABEY, E., MAZZA, G., BAYINDIRLI, L., \& ARTIK, N. Extraction of bioactive compounds from milled grape canes (Vitis vinifera) using a pressurized low-polarity water extractor. Food and bioprocess technology, 5(1), 359-371. (2012).

Alina Lenuța CRĂCIUN, Gheorghe GUTT, Study on extraction and purification of trans-resveratrol from grape cane - A review, Food and Environment Safety, Volume XX, Issue - 2021, pag. 113 - 127 